Web Jurnal:

http://ejournal.kemenperin.go.id/jli

\title{
Pengaruh penambahan tepung agar terhadap komposisi kimia serbuk agar dari kolang-kaling
}

\section{Addition effect of agar flour on chemical composition of kolang-kaling agar powder}

Inda Three Anova* dan K Kamsina

Balai Riset dan Standardisasi Industri Padang

Jl. Raya LIK No. 23 Ulu Gadut, Padang, Indonesia

*indova99@gmail.com

\begin{tabular}{l}
\hline INFO ARTIKEL \\
\hline Sejarah artikel: \\
Diterima: \\
4 Oktober 2019 \\
Direvisi: \\
13 Desember 2019 \\
Diterbitkan: \\
30 Desember 2019
\end{tabular}

Kata kunci:

kolang-kaling;

agar-agar;

serbuk agar

\begin{abstract}
ABSTRAK
Pemanfaatan kolang-kaling sebagai produk pangan dalam bentuk serbuk memberikan nilai tambah bagi buah tersebut. Buah ini memiliki kandungan mineral yang cukup banyak, seperti: potassium, besi dan kalsium yang bermanfaat dan dapat memperlancar proses metabolisme dalam tubuh. Tujuan dari penelitian ini adalah untuk melihat pengaruh dari penambahan konsentrasi tepung agar pada pembuatan serbuk agar dari kolang-kaling. Penelitian dilakukan dengan penambahan tepung agar 1\%, 2\%, 3\% dan $4 \%$ pada bubur kolang kaling. Hasil penelitian menunjukkan bahwa penambahan tepung agar secara statistik tidak berbeda nyata terhadap kadar air, kadar abu, kadar serat kasar, kadar karbohidrat dan jenis ikatan rangkap (uji FTIR), tetapi berbeda nyata pada tingkat kepercayaan 95\% pada kadar beberapa mineral alami yaitu fosfor, kalsium dan besi. Perlakuan optimal didapatkan pada perlakuan penambahan tepung agar $2 \%$ dengan nilai kadar air 4,98\%, kadar abu 0,49\%, kadar serat 5,19\%, kadar karbohidrat 64,29\% dan mineral fosfor $400 \mathrm{ppm}$, kalsium 292,8 ppm dan besi 44,8 ppm, serta absorpsi air 10 kali. Produk memenuhi SNI 01-2802-1995 tepung agar-agar untuk kadar air, abu dan absorpsi air.
\end{abstract}

\begin{abstract}
The utilization of kolang-kaling fruit as a food product in powder form can add the value of the fruit. The fruit has a lot of mineral content, such as: potassium, iron, and calcium which are useful and can facilitate the body metabolic processes. The research purpose was to find the addition effect of the concentration of agar flour in the making of kolang-kaling agar powder. The research was done with the addition of agar flour 1\%, $2 \%, 3 \%$ and $4 \%$ into kolang-kaling puree. The results showed that the addition of agar flour statistically had no significant different to the water content, ash content, crude fiber content, carbohydrate content and type of double bond (FTIR test), but significantly different at 95\% confidence on some natural minerals namely phosphorus, calcium and iron. The optimal treatment was obtained in the addition of $2 \%$ agar flour with a moisture content $4.98 \%$, ash content $0.49 \%$, fiber content $5.19 \%$, carbohydrate content $64.29 \%$ and minerals phosphorus 400 ppm, calcium $292.8 \mathrm{ppm}$ and iron $44.8 \mathrm{ppm}$ with 10 times water absorption. Products meet the SNI 01-2802-1995 agar-agar powder for moisture content, ash content, and water absorption.
\end{abstract}

(C) 2019 Penulis. Dipublikasikan oleh Baristand Industri Padang. Akses terbuka dibawah lisensi CC BY-NC-SA

\section{Pendahuluan}

Aren (Arenga pinnata Merr) merupakan tumbuhan serbaguna. Populasinya sebagian besar tumbuh secara liar dan tersebar secara alami, baik didataran rendah, lereng bukit, lembah maupun pengunungan (Manambangtua et al., 2018). Hampir setiap bagian pohon aren dapat dimanfaatkan, akar aren dimanfaatkan untuk obat tradisional, batang aren untuk berbagai macam peralatan dan bangunan, daun muda/janur aren 
untuk pembungkus kertas rokok. Buah aren muda dapat diolah menjadi kolang-kaling, air nira untuk gula merah/cuka dan pati/tepung dalam batang untuk berbagai macam makanan (Purwati and Nugrahini, 2018).

Kolang-kaling dapat dimanfaatkan untuk bahan aneka makanan dan minuman, kandungan seratnya juga baik untuk kesehatan. Serat kolang kaling yang masuk ke dalam tubuh menyebabkan proses pembuangan air besar teratur sehingga dapat mencegah kegemukan atau obesitas (Tusiyem et al., 2015)

Kolang-kaling adalah endosperm biji buah aren matang dan setelah melalui proses pengolahan maka benda ini mejadi lunak, kenyal, dan berwarna putih agak bening. Pemanfaatan kolang-kaling saat ini masih sangat terbatas (Sarmi et al., 2016). Kerusakan yang banyak terjadi pada kolang kaling adalah perubahan warna cokelat yang disebabkan oleh oksidasi dari enzim Polifenol oksidase (PPO) dan perubahan tekstur yang menyebabkan kolang kaling menjadi lebih lembek (Dameswari, 2017). Biasanya hanya dikonsumsi sebagai manisan atau makanan penutup (Hussin et al., 2017), padahal kolang-kaling memiliki kandungan kimia yang baik untuk kesehatan (Lempang, 2012).

Kadar air kolang-kaling yang sangat tinggi mencapai 93,6\% disamping juga mengandung protein 2,344\%, karbohidrat $56,571 \%$ serat kasar $10,524 \%$ (Sarmi et al., 2016). Sedangkan menurut (Berta et al., 2017), dalam 100 gram kolang-kaling terdapat kalori $27 \mathrm{kkal}$, protein 0,4 gram, lemak 0,2 gram, karbohidrat 6 gram, kalsium $91 \mathrm{mg}$, posfor $243 \mathrm{mg}$, serat 1,6 g, dan zat besi 0,5 mg. Kandungan gizi kolang-kaling bermanfaat bagi kesehatan seperti dapat memulihkan stamina, menyegarkan, serta memperlancar metabolisme tubuh. Manfaat tersebut sangat baik sehingga kolang-kaling dapat dikonsumsi sebagai produk pangan meskipun penampilannya kurang menarik dari segi warna dan aroma, serta tidak berasa, tetapi kolang-kaling telah dijadikan manisan, permen jelly, dan yang paling sering digunakan oleh masyarakat adalah untuk campuran es buah serta minuman segar lainnya.

Manisan kolang-kaling dapat disimpan lama karena mempunyai kadar gula tinggi, $\mathrm{pH}$ rendah, serta dilakukannya pengemasan yang baik. Manisan yang dikemas dengan baik akan terhindar dari kontaminasi lingkungan, sehingga produk tetap terjaga dan lebih tahan lama. Manisan kolang-kaling basah yang dikemas diperkirakan dapat bertahan 2-3 minggu pada temperatur rendah dan jika disimpan di dalam lemari pendingin daya tahannya diperkirakan 3-4 minggu. Penyebab kerusakan manisan kolang-kaling karena tumbuhnya mikroorganisme, terutama khamir yang tumbuh pada makanan yang mengandung gula. Selama ini manisan kolang-kaling basah dijual tanpa pengemasan yang memadai sehingga mempengaruhi mutu dan masa simpan produk tersebut misalnya akan mudah terkontaminasi dengan lingkungan sekitarnya sehingga tidak dapat bertahan lama (Safriani et al., 2014).

Penelitian tentang kolang-kaling telah banyak dilakukan, diantaranya adalah penelitian pengemasan untuk manisan kolang-kaling (Safriani et al., 2014), penelitian pemanfaatan buah kolang-kaling untuk untuk manisan kering (fruit leather) yang dicampur dengan buah nangka yang menyatakan bahwa campuran kedua buah tersebut tidak mempengaruhi kandungan betakaroten dan aktivitas antioksidan bahan yang bersangkutan (Yenrina et al., 2017), dan penelitian pemanfaatan kolang kaling menjadi permen jeli yang termasuk dalam makanan semi basah yang dibuat dari buah dan bahan pembentuk gel, dengan kenampakan jernih dan transparan, serta mempunyai tekstur dan kekenyalan tertentu (Hartati et al., 2016)

Tingginya kadar air pada kolang-kaling menjadi isolat yang tepat untuk pertumbuhan mikroba. Oleh karena itu, dibutuhkan teknologi pengawetan yang dapat meningkatkan daya simpan dari kolang-kaling tersebut. Cara yang dapat dilakukan adalah membuat kolangkaling menjadi bentuk serbuk melalui proses pengeringan. Penelitian pemanfaatan buah kolang kaling menjadi serbuk telah dilakukan (Fitrilia et al., 2019) yang menyatakan bahwa pembuatan serbuk dapat dilakukan dengan cara pengeringan menggunakan oven gelombang mikro. Serbuk kolang kaling dianalisis secara fisik dan kimia yang terdiri atas rendemen, warna dan proksimat. Hasil penelitian menunjukkan bahwa rendemen sampel uji berkisar 6,97 - 8,89\%, warna serbuk kolang kaling memiliki nilai kecerahan (L) sebesar 71,87 - 83,09.

Para pengrajin kolang-kaling biasanya melakukan perendaman kolang-kaling selama 3 hari hingga tercium aroma khas kolang-kaling. Perendaman merupakan salah satu proses yang dilakukan dalam pengolahan kolangkaling (Irwanto and Sahupala, 2015). Perendaman yang dilakukan adalah dengan menggunakan air bersih atau larutan tepung beras. Air dapat membersihkan kotoran pada bahan pangan (Haris et al., 2013)

Pengeringan kolang-kaling dilakukan untuk menurunkan aktivitas air dengan cara menguapkan air dari bahan pangan. Aktivitas air yang rendah dapat mencegah resiko kerusakan bahan akibat aktivitas enzimatis dan biologi sehingga bahan pangan dapat dijaga kualitasnya selama proses penyimpanan. Pengeringan merupakan aspek penting dalam pengolahan makanan dan merupakan teknik umum dalam pengawetan untuk menghasilkan bentuk baru produk yang diinginkan (Mechlouch et al., 2012).

Agar-agar tepung adalah polisakarida berupa tepung yang diperoleh dari ekstrasi agarophyte, bersifat koloid bila dilarutkan dalam air mendidih dan menggumpal bila didinginkan (reversible) (BSN, 1995). Agar-agar dapat dibentuk sebagai bubuk dan dijual di pasaran. Apabila dilarutkan dalam air panas dan didinginkan agar-agar akan menjadi padatan lunak dan bertekstur kenyal. Banyak olahan makanan yang menggunakan agar-agar seperti campuran es krim dan puding jeli. Fungsi utama agar-agar adalah sebagai pemantap (stabilizer), pembuat emulsi (emulsifier), bahan pengental (thickening), bahan pengisi (icing) dan bahan pembuat gel (gelling agent) (Yuliani et al., 2012).

Salah satu sumber polisakarida yang terdapat pada kolang-kaling yaitu galaktomanan. Pemanfaatan sumber galaktomanan dalam kolang-kaling masih sangat terbatas dan tingkat konsumsi masyarakat juga masih rendah. Galaktomanan adalah polisakarida yang terdiri dari rantai manosa dan galaktosa yang umumnya digunakan sebagai penggumpal dan bersifat sebagai hidrokoloid juga dapat digunakan sebagai gum untuk produk pangan 
olahan. Galaktomanan memiliki sifat yang stabil pada suhu tinggi dan kemampuan membentuk gel dengan bobot molekul yang relatif besar. Galaktomanan juga bersifat pengental dan penstabil emulsi yang baik serta dapat mengurangi resiko masuknya racun atau bersifat antioksidan jika digunakan sebagai bahan farmasi dan industri makanan (Sarmi et al., 2016).

Berdasarkan informasi tersebut diatas dengan kandungan gizi yang banyak serta manfaat yang didapat dari kolang-kaling, maka perlu dilakukan alternatif produk pangan olahan dari kolang-kaling salah satunya yaitu untuk pembuatan serbuk agar kolang-kaling. Tujuan dari penelitian ini adalah untuk mendapatkan ketersediaan serbuk agar kolang-kaling yang optimal dengan penambahan tepung agar-agar pada pembuatan serbuk agar kolang-kaling.

\section{Metode}

Penelitian dilakukan di Laboratorium proses untuk pembuatan produk dan laboratorium pengujian produk di Balai Riset dan Sandardisasi Industri Padang dan Laboratorium Fakutas Teknlogi Pertanian Universitas Andalas Padang serta uji FTIR di Laboratorium Universitas Negeri Padang.

Bahan baku yang digunakan adalah buah kolangkaling yang didapatkan di Pasar pagi Raden Saleh Padang Sumatera Barat. Bahan baku kolang-kaling yang digunakan dibedakan antara kolang kaling yang berukuran besar (panjang $\pm 4-5 \mathrm{~cm}$, tekstur lebih lunak) dan kolang-kaling yang berukuran lebih kecil (panjang $\pm 1-2 \mathrm{~cm}$, tekstur lebih keras). Bahan agar-agar (merk Swallow) dari toko terdekat dan aquadest.

Peralatan proses yang digunakan adalah blender (merk Phillips), tampah, panci stainless, kompor, spatula, peralatan gelas untuk pengujian dan oven pengering (alat hasil rekayasa peneliti Baristand Industri Padang). Peralatan pengujian diantaranya oven (merk Memert), FTIR spectrum one spectrometer (merk Perkin Elmer) dan peralatan lain yang terkait dengan pengujian.

\subsection{Rancangan penelitian}

Penelitian pembuatan serbuk agar dari buah kolangkaling dilakukan dengan penambahan jeli agent, dimana yang digunakan adalah tepung agar-agar yang telah beredar di pasaran (merk Swallow). Variasi penambahan tepung agar yang dilakukan adalah dengan konsentrasi $1 \%$ (A), 2\% (B), 3\% (C) dan 4\% (D) pada bubur kolangkaling. Rancangan percobaan dilakukan dengan Rancangan Acak Lengkap dengan 3 ulangan. Apabila data yang diperoleh yang dianalisis secara statistik dengan uji $\mathrm{F}$ hitung menunjukkan hasil yang berbeda nyata akan dilanjutkan dengan uji lanjut DNMRT pada taraf nyata $5 \%$.

\subsection{Pelaksanaan penelitian}

\subsubsection{Pembuatan serbuk agar kolang kaling (Fitrilia et al., 2019)}

Pembuatan serbuk agar dari kolang-kaling dimulai dengan mencuci kolang-kaling secara berulang dua sampai tiga kali pencucian. Kemudian kolang-kaling basah ditimbang, ditambahkan air 1:1 (b/v) dan dihaluskan menggunakan blender hingga menjadi bubur, diukur sesuai kebutuhan, kemudian ditambahkan jeli agent (tepung agar-agar) sesuai dengan perlakukan (b/v) dan dilakukan pengadukan kembali hingga tepung agar dan bubur kolang-kaling tersebut homogen. Setelah homogen bubur diratakan pada loyang pengering setipis mungkin untuk dilanjutkan dengan pengeringan pada oven pengering suhu $\pm 60^{\circ} \mathrm{C}$ selama 23 hari. Setelah didapatkan kolang-kaling dalam bentuk kering kemudian dihaluskan dengan menggunakan blender sampai berbentuk tepung dengan lolos ayakan 80 mesh. Serbuk agar kolang-kaling kemudian dikemas dengan menggunakan plastik poli propilen dan dilakukan karakterisasi.

\subsection{Analisis serbuk agar kolang-kaling}

Metode analisis yang dilakukan terhadap serbuk agar kolang-kaling adalah: kadar air, kadar abu, kadar serat kasar secara gravimetri, kadar karbohidrat (metode titrasi) dan mineral logam serbuk (Atomic Absorption Spektrofomometri) serta uji Fourier Trasnform Infra Red (FTIR) untuk melihat ikatan kimia yang terbentuk.

\section{Hasil dan pembahasan}

\subsection{Pengamatan bahan baku kolang kaling kering dalam bentuk bubuk}

Kolang-kaling sebagai bahan baku untuk pembuatan serbuk dianalisis antara lain: kadar air, kadar abu, kadar karbohidrat, kadar serat kasar dan mineral seperti kalsium dan besi. Bahan baku kolang-kaling yang analisis ada 2 jenis yang dibedakan menurut ukuran dan tekstur. Hasil analisis dapat dilihat pada Tabel 1.

Tabel 1.

Analisis serbuk kolang-kaling

\begin{tabular}{|c|c|c|c|c|}
\hline \multirow[b]{2}{*}{ No } & \multirow[b]{2}{*}{ Analisis } & \multirow[b]{2}{*}{ Satuan } & \multicolumn{2}{|c|}{ Jenis kolang kaling } \\
\hline & & & $\begin{array}{l}\text { Besar (pipih, } \\
\text { lunak) }\end{array}$ & $\begin{array}{l}\text { Kecil (bulat, } \\
\text { keras) }\end{array}$ \\
\hline 1 & Rendemen & $\%$ & 3,8 & 4,2 \\
\hline 2 & Kadar air & $\%$ & 3,1 & 2,8 \\
\hline 3 & Kadar abu & $\%$ & 0,53 & 0,53 \\
\hline 4 & Kadar serat Kasar & $\%$ & 7,18 & 8,08 \\
\hline 5 & Kadar Karbohidrat & $\%$ & 71,56 & 70,93 \\
\hline 6 & Kadar Kalsium & ppm & 420,44 & 454,66 \\
\hline 7 & Kadar P2O5 & ppm & 500 & 500 \\
\hline 8 & Kadar Besi & $\mathrm{ppm}$ & 18,43 & 21,49 \\
\hline
\end{tabular}

Analisis serbuk kolang-kaling sebagai bahan baku untuk pembuatan serbuk agar memiliki kadar air yang berbeda dari dua jenis yang dianalisis. Untuk serbuk dari kolang-kaling yang berukuran lebih besar (pipih dan lunak) memiliki kadar air yang lebih tinggi dibandingkan dari jenis kolang-kaling yang berukuran lebih kecil (bulat dan keras). Sedangkan untuk kadar abu memilki jumlah yang sama.

Hasil analisis kadar serat kasar, kadar kalsium dan kadar besi, untuk serbuk dari jenis kolang-kaling yang berukuran lebih kecil (bulat dan keras) memilki nilai yang lebih tinggi jika dibandingkan dengan nilai hasil 
analisis untuk parameter yang sama pada jenis kolangkaling yang berukuran besar (pipih dan lunak), kecuali karbohidrat, terutama untuk nilai analisis kadar mineral kalsium dan besi yang selanjutnya untuk penelitian digunakan kolang-kaling yang berukuran kecil. Terjadinya perbedaan nilai kandungan dari buah kolangkaling ini bisa disebabkan karena berbagai faktor, seperti varitas, tempat hidup, umur panen, perlakuan pengolahan pasca panen ( proses pengolahan, waktu dan suhu).

Tingginya kandungan kalsium, besi, karbohidrat dan serat ini menyebabkan kolang-kaling bisa dijadikan sebagai bahan makanan sumber mineral yang dapat berfungsi sebagai terapi sendi sedangkan serat untuk membantu menjalankan diet tubuh bagi penderita obesitas dan memperlancar pencernaan, maka penggunaan kolang-kaling sebagai sumber serat dalam bahan makanan merupakan salah satu alternatif yang dilakukan dalam upaya memenuhi kebutuhan tubuh akan serat.

Gambar serbuk kolang kaling dapat dilihat pada Gambar 1. Tampak pada gambar bahwa warna serbuk kolang-kaling yang dihasilkan jika dibandingkan dengan bahan segar mengalami perubahan warna, yaitu menjadi kecoklatan. Terjadinya perubahan warna ini dapat disebabkan karena terjadinya reaksi enzimatis (karamelisasi dan reaksi mailard) (Lakshmi, 2014; Sarastuti and Yuwono, 2015).

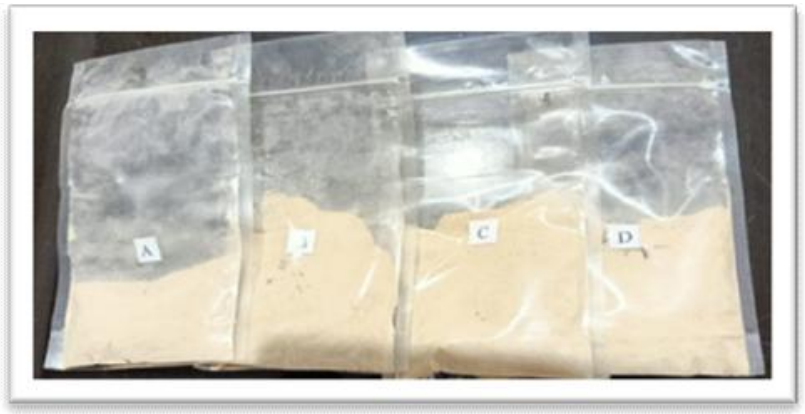

Gambar 1. Serbuk agar kolang-kaling

\subsection{Kadar karbohidrat}

Kadar karbohidrat serbuk agar kolang-kaling dapat dilihat hasilnya pada Gambar 2. Berdasarkan Gambar 2, dapat dilihat bahwa kadar karbohidrat serbuk kolangkaling mengalami penurunan seiring dengan bertambahnya konsentrasi penambahan tepung agar yang digunakan. Kadar karbohidrat tertinggi didapatkan pada perlakuan A dan yang terendah didapatkan pada perlakuan D. Terjadinya penurunan nilai karbohidrat seiring dengan meningkatnya nilai kadar serat dari serbuk, dimana semakin tinggi penambahan tepung agar akan menyebabkan nilai kadar serat naik, dan kadar karbohidrat menurun.

Perlakuan penambahan tepung agar untuk nilai karbohidrat pada pembuatan serbuk kolang-kaling tidak berbeda nyata menurut uji Duncan pada taraf nyata $5 \%$. Bila dibandingkan dengan nilai karbohidrat dari bahan baku serbuk kolang-kaling terjadi penurunan nilai karbohidrat. Tetapi bila dibandingkan dengan analisis proksimat yang lain, komponen karbohidrat lebih banyak daripada komponen lainnya. Hal ini menunjukkan karbohidrat merupakan penyumbang kalori tertinggi dari serbuk agar kolang-kaling.

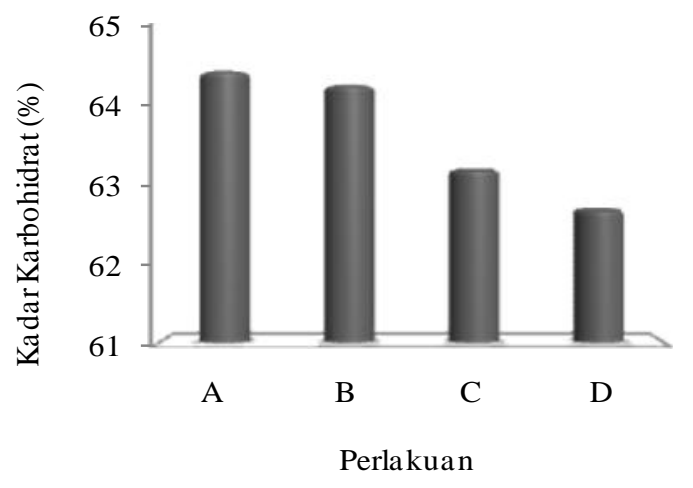

Gambar 2. Kadar karbohidrat serbuk agar kolang-kaling Ket : Perlakuan $\mathrm{A}=$ penambahan tepung agar $1 \%, \mathrm{~B}=$ penambahan tepung agar $2 \%, \mathrm{C}=$ penambahan tepung agar $3 \%, \mathrm{D}=$ penambahan tepung agar $4 \%$.

Kandungan karbohidrat yang dimiliki kolang-kaling bisa memberikan rasa kenyang bagi orang yang mengkonsumsinya, selain itu juga menghentikan nafsu makan dan mengakibatkan konsumsi makanan jadi menurun, sehingga cocok dikonsumsi sebagai makanan diet. Kolang-kaling juga dapat digunakan sebagai coktail dan makanan ringan lokal seperti kolak. Karbohidrat di dalam kolang-kaling pada umumnya adalah galaktomanan dengan berat molekul beragam (Purwati and Nugrahini, 2018; Tarigan, 2012).

Sedangkan menurut (Ratima, 2014), menyatakan bahwa kolang-kaling mengandung 52,9\% karbohidrat. Karbohidrat dalam daging kolang-kaling umumnya adalah galaktomannan. Dalam dunia farmasi galaktomannan ini menjadi bahan obat beberapa jenis penyakit seperti radang sendi. Galaktomannan berefek analgesik atau pereda sakit sehingga dapat mengurangi rasa sakit pada radang sendi.

\subsection{Kadar serat}

Data hasil analisis kadar serat serbuk agar kolangkaling seperti tampak pada Gambar 3.

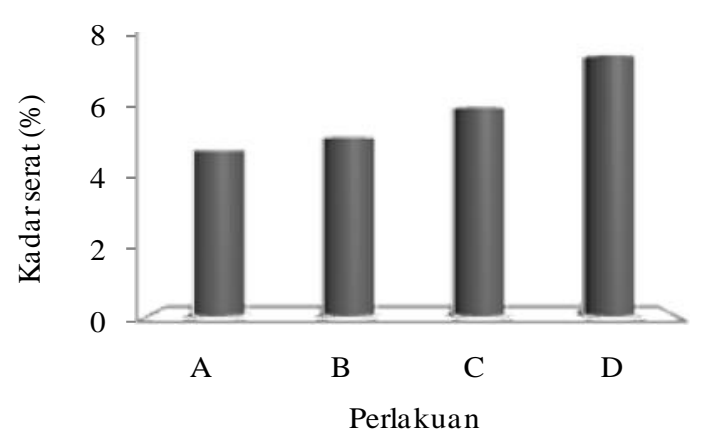

Gambar 3. Kadar serat serbuk agar kolang-kaling Ket. Perlakuan: A: penambahan tepung agar 1\%), B: penambahan tepung agar $2 \%$, C: penambahan tepung agar $3 \%$, D: penambahan tepung agar $4 \%$. 
Pada Gambar 3 terlihat bahwa kadar serat tertinggi didapatkan pada perlakuan D yaitu $7,54 \%$ dan tidak berbeda nyata dengan perlakuan lainnya. Perlakuan penambahan tepung agar pada pembuatan serbuk agar dari kolang-kaling memberikan nilai kadar serat yang semakin tinggi dengan semakin banyaknya konsentrasi tepung agar yang ditambahkan. Akan tetapi jika dibandingkan dengan kadar serat kasar awal dari bubuk kolang-kaling yang dikeringkan terjadi penurunan untuk beberapa perlakuan.

Terjadinya kenaikan kadar serat dari serbuk agar kolang-kaling ini disebabkan karena tepung agar-agar memiliki kadar serat yang lebih tinggi dibandingkan dengan kolang-kaling, sehingga semakin tinggi penambahan tepung agar yang ditambahkan akan menyebabkan semakin tinggi kadar serat kasar serbuk kolang-kaling yang didapatkan. Serat kolang-kaling dan serat dari bahan makanan lain yang masuk ke dalam tubuh dapat melancarkan proses pembuangan air besar teratur sehingga dapat mencegah kegemukan (obesitas), penyakit jantung koroner, kanker usus, dan penyakit kencing manis (Purwati and Nugrahini, 2018)

Komponen karbohidrat yang tidak dapat dihidrolisis oleh asam basa atau tidak dicerna oleh usus manusia adalah serat. Nilai total karbohidrat biasanya lebih besar dari nilai serat kasar dan bagian yang tidak dapat diserap oleh tubuh dan tidak dihitung sebagai bagian dari nilai gizi, sedangkan menurut (Siregar et al., 2015) serat kasar dapat dijadikan indikasi untuk menentukan kualitas dari bahan pangan yang dikeringkan.

\subsection{Kadar mineral}

Kolang-kaling memiliki kandungan mineral yang cukup tinggi, kadar mineral serbuk kolang kaling seperti tampak pada Gambar 4.

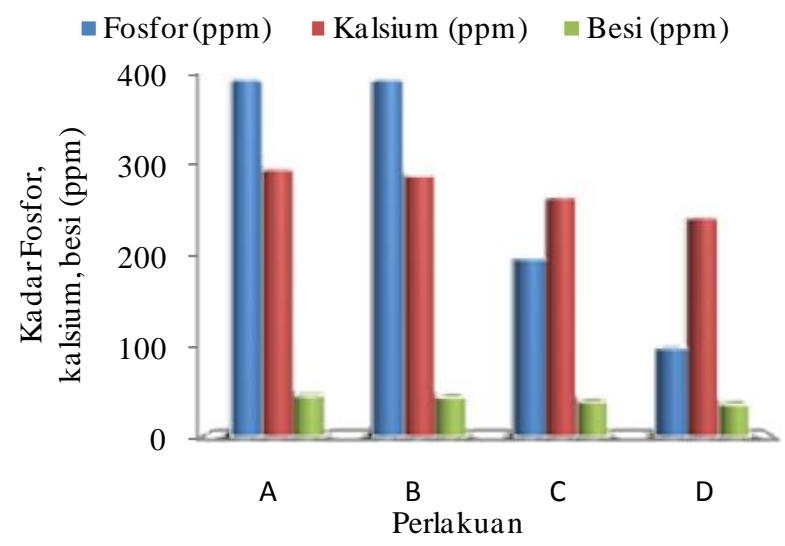

Gambar 4. Kadar mineral fosfor, kalsium, dan besi serbuk agar kolang-kaling

Ket: Perlakuan $\mathrm{A}=$ penambahan tepung agar $1 \%, \mathrm{~B}=$ penambahan tepung agar $2 \%, \mathrm{C}=$ penambahan tepung agar $3 \%, \mathrm{D}=$ penambahan tepung agar $4 \%$.

Kadar mineral fosfor, kalsium, dan besi serbuk agar kolang-kaling pada Gambar 4, menunjukkan bahwa kadar fosfor tertinggi didapatkan pada perlakuan A dan B yang berbeda nyata dengan perlakuan lainnya. Kadar kalsium yang tertinggi didapatkan pada perlakuan A dan tidak memberikan pengaruh yang nyata dengan perlakukan lainnya. Sedangkan untuk kadar besi relatif hampir sama dan tidak berbeda nyata antara sesama perlakuan lainnya.

Pada gambar di atas juga tampak bahwa rata-rata untuk ketiga pengamatan kadar mineral yang dilakukan terjadi penurunan nilai kandungan mineral seiring dengan bertambahnya konsentrasi pemakaian tepung agar yang digunakan. Hal ini bisa disebabkan dengan bertambahnya tepung agar yang digunakan akan mengurangi jumlah dari kolang-kaling yang digunakan, yang tentunya juga akan mengurangi kandungan mineral yang terdapat pada serbuk kolang-kaling yang dihasilkan.

Kandungan mineral dalam setiap 100 gram kolangkaling basah yaitu energi $27 \mathrm{kkal}$, kalsium $91 \mathrm{mg}$, fosfor $243 \mathrm{mg}$ dan zat besi $0,5 \mathrm{mg}$ serta kadar air mencapai $94 \%$ (Purwati and Nugrahini, 2018). Nilai kandungan mineral ini bila dibandingkan setelah menjadi serbuk agar kolang kaling mengalami peningkatan. Tingginya kandungan mineral seperti kalsium, besi dan fosfor sangat berkhasiat menjaga tubuh tetap bugar dan sehat. Sedangkan kandungan potasium, besi, kalsium, vitamin $A$, vitamin $B$, vitamin $C$, dan gelatin yang dapat dicerna oleh tubuh berfungsi untuk mensintesa kolagen.

\subsection{Kadar air}

Kadar air merupakan persentase air yang terdapat pada bahan. Kadar air serbuk agar kolang-kaling dapat dilihat pada Gambar 5. Pada Gambar 5 dapat dilihat bahwa kadar air tertinggi didapatkan pada perlakuan B yaitu $4,98 \%$ dan kadar air terendah didapatkan pada perlakuan D yang tidak berbeda nyata dengan perlakuan lainnya. Namun apabila dilihat secara keseluruhan tampak bahwa terjadi penurunan kadar air serbuk yang didapatkan seiring dengan meningkatnya penambahan tepung agar yang digunakan. Akan tetapi jika dibandingkan dengan kadar air serbuk kolang-kaling terjadi kenaikan.

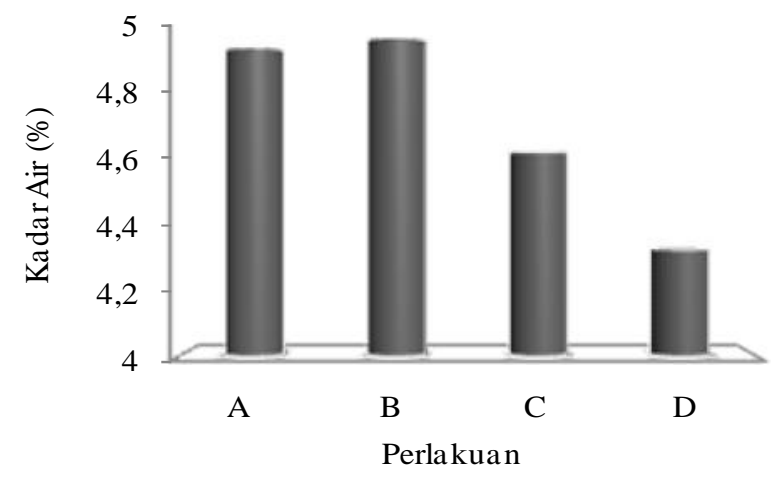

Gambar 5 . Kadar air serbuk agar kolang-kaling

Ket : Perlakuan $\mathrm{A}=$ penambahan tepung agar $1 \%, \mathrm{~B}=$ penambahan tepung agar $2 \%, \mathrm{C}=$ penambahan tepung agar $3 \%, \mathrm{D}=$ penambahan tepung agar $4 \%$. 
Terjadinya perbedaan kadar air serbuk agar kolangkaling yang didapatkan selain karena perlakuan penambahan tepung agar juga karena proses pengeringan dalam oven atau pemanasan yang kurang merata. Kadar air serbuk agar masih memenuhi SNI 01-2802-1995 tentang tepung agar-agar yaitu maksimal 17\% (BSN, 1995).

\subsection{Kadar abu}

Kadar abu dari serbuk kolang-kaling dapat dilihat pada Gambar 6. Abu merupakan residu anorganik hasil oksidasi senyawa organik bahan pangan. Dari Gambar 6 dapat dilihat bahwa kadar abu dari serbuk agar kolangkaling berkisar antara $0,44-0,49 \%$ dan tidak berbeda nyata dengan perlakukan lainnya. Kadar abu serbuk agar kolang-kaling masih memenuhi SNI 01-2802-1995 tentang tepung agar-agar yaitu maksimal 0,5\% (BSN, 1995).

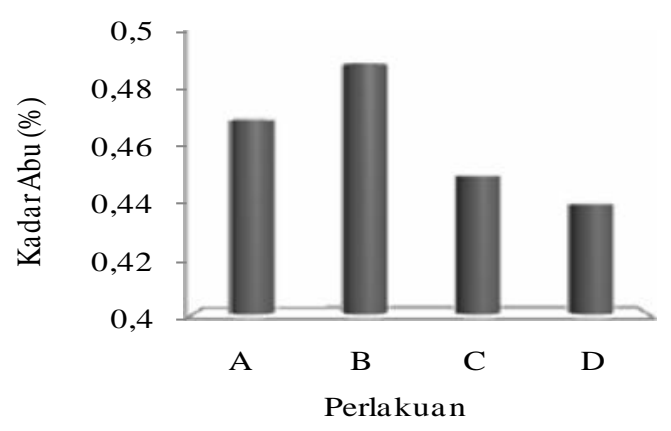

Gambar 6. Kadar abu serbuk agar kolang-kaling

Ket : Perlakuan $\mathrm{A}=$ penambahan tepung agar $1 \%, \mathrm{~B}=$ penambahan tepung agar $2 \%, \mathrm{C}=$ penambahan tepung agar $3 \%, \mathrm{D}=$ penambahan tepung agar $4 \%$

Abu merupakan unsur mineral zat anorganik yang tidak mudah menguap dan merupakan sisa yang tertinggal setelah contoh dibakar dan dipijarkan sampai bebas karbon dan air. Kadar abu yang terkandung pada suatu produk menunjukkan tingkat kemurnian produk tersebut. Tingkat kemurnian sangat dipengaruhi oleh komposisi dan kandungan mineralnya (Yuliani et al., 2012).

\subsection{Pengujian FTIR serbuk agar kolang-kaling}

Ikatan kimia yang terdapat pada serbuk kolangkaling dapat diketahui dengan melakukan pengujian FTIR. Adanya puncak-puncak yang berbeda pada pengujian FTIR menunjukan bahwa terdapat beberapa jenis ikatan kimia yang berbeda. Serbuk yang dilakukan pengujian FTIR adalah serbuk agar kolang-kaling yang dengan perlakuan A2 dan bahan baku serbuk kolangkaling, Gambar hasil pengujian FTIR serbuk kolangkaling dapat dilihat pada Gambar 7 dan 8 .

Hasil pembacaan spektrum bahan baku (Gambar 7) serbuk kolang kaling sama halnya dengan pembacaan spektrum agar kolang-kaling dengan menggunakan Fourier Transfer Infrared (FTIR) pada bilangan gelombang $4000 \mathrm{~cm}^{-1}$ sampai dengan bilangan gelombang $600 \mathrm{~cm}^{-1}$. Bila dilihat gambar hasil uji FTIR antara bahan baku serbuk dan serbuk agar kolang-kaling terlihat peak peak yang terbentuk hampir sama dan streching ikatan gelombang yang tidak jauh berbeda bilangan gelombangnya. Dari hasil pengujian untuk bahan baku serbuk (Gambar 7) kolang-kaling terdapat ikatan O-H streching pada puncak gelombang 3640,91 $\mathrm{cm}^{-1}$, ikatan C-H Stretching pada $2854.03 \mathrm{~cm}^{-1}$, ikatan $\mathrm{C}=\mathrm{C}$ pada puncak gelombang $2275.44 \mathrm{~cm}^{-1}, 2170.03$ $\mathrm{cm}^{-1}$ dan $\mathrm{C}=\mathrm{O}$ stretching pada $1748.18 \mathrm{~cm}^{-1}$.

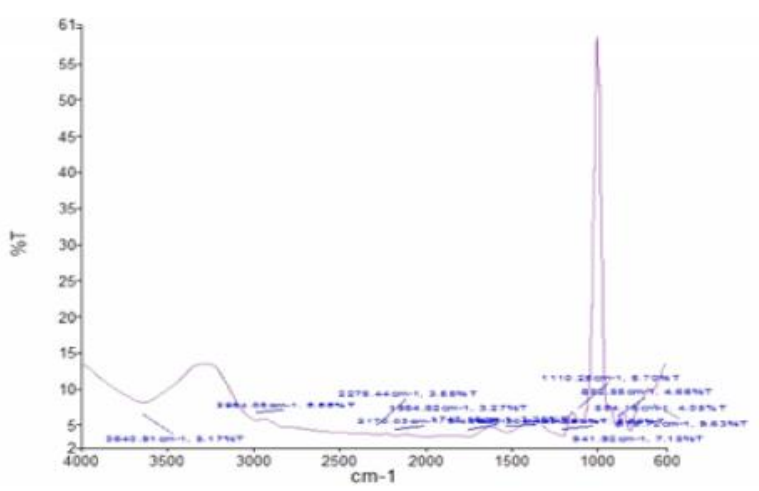

Gambar 7. Spektrum FTIR bahan baku kolang-kaling

Gambar 8 menunjukkan hasil uji FTIR serbuk agar kolang-kaling. Dari hasil pengujian tersebut dapat dilihat bahwa serbuk agar kolang kaling perlakuan A2 terdapat ikatan O-H stretching pada puncak gelombang 3648.53 $\mathrm{cm}^{-1}$, C-H Stretching pada $2882.08 \mathrm{~cm}^{-1}$, C-C cincin pada puncak gelombang $2128.29 \mathrm{~cm}^{-1}$, dan $\mathrm{C}=\mathrm{O}$ stretching pada $1743.37 \mathrm{~cm}^{-1}$.

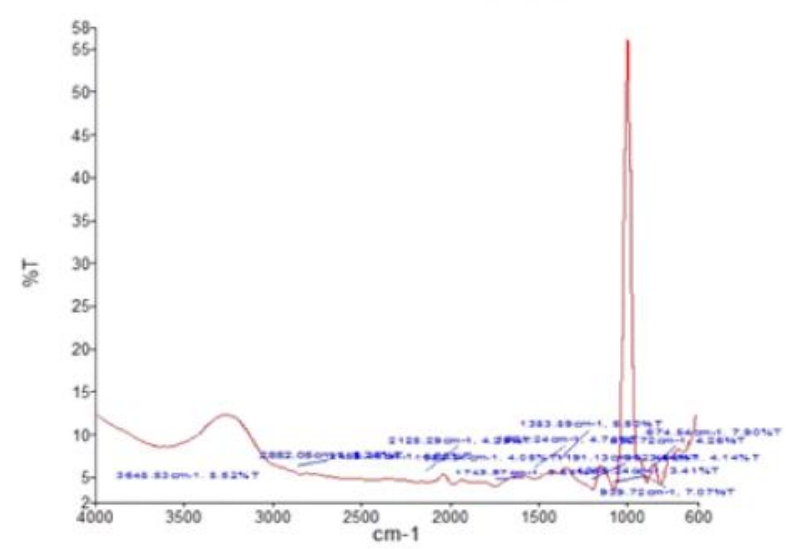

Gambar 8. Spektrum FTIR serbuk agar kolang-kaling

\subsection{Uji coba pemasakan serbuk agar kolang-kaling}

Serbuk agar dari buah kolang-kaling yang didapatkan selanjutnya dilakukan proses pemasakan. Proses pemasakan serbuk agar dilakukan dengan penambahan air sebanyak 1:10 (10 g serbuk agar kolang-kaling dalam $100 \mathrm{ml}$ air) gula dan garam secukupnya. Setelah ditambahkan air dilakukan pemanasan sampai mendidih/masak dicetak dan biarkan 
dingin. Hasil pemasakan serbuk agar kolang-kaling seperti tampak pada Gambar 9.

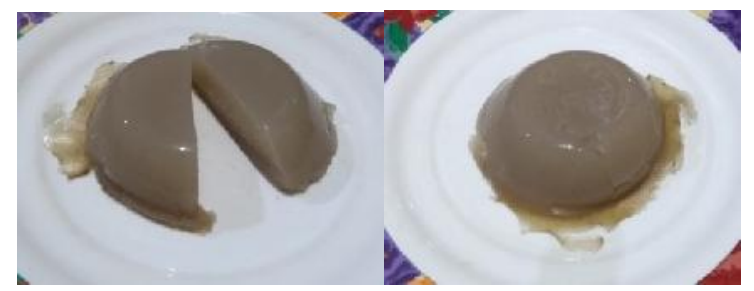

Gambar 9. Agar kolang-kaling setelah proses pemasakan

Pada Gambar 9 terlihat bahwa serbuk agar kolangkaling yang telah dimasak terjadi perubahan warna, yaitu berwarna lebih coklat dibandingkan dengan warna bahan baku kolang kaling yang lebih cerah, perubahan ini bisa disebabkan karena selama dalam proses pengolahan terjadi reaksi browning atau pencoklatan. Reaksi pencoklatan merupakan reaksi penting yang terjadi selama proses pengolahan makanan (Simpson, 2012). Akumulasi pigmen berwarna coklat merupakan indikasi yang menunjukkan terjadinya reaksi Maillard pada makanan yang mengandung protein dan karbohidrat. Reaksi Maillard selain menyebabkan pencoklatan juga mempengaruhi flavor, teksur, dan rasa dari makanan melalui protein cross linking, dan degradasi Strecker (Agustini et al., 2015)

\section{Kesimpulan}

Perlakuan penambahan tepung agar yang berbeda pada pembuatan serbuk agar kolang-kaling tidak memberikan pengaruh yang nyata secara statistik pada kadar serat, kadar karbohidrat, kadar air, dan kadar abu. Penambahan tepung agar yang berbeda memberikan pengaruh yang nyata secara statistik pada kandungan mineral fosfor, kalsium dan besi dari serbuk agar kolangkaling yang dihasilkan. Perlakuan optimal didapatkan pada perlakuan penambahan tepung agar $2 \%$ dengan kadar serat 5,19\%, kadar karbohidrat 64,29\%, kadar air $4,98 \%$, kadar abu 0,49\%, kadar mineral fosfor $400 \mathrm{ppm}$, kalsium 292,76 ppm dan besi 44,8 ppm. Uji spectrum FTIR dari serbuk agar kolang-kaling dan serbuk kolangkaling ikatan kimia yang terbentuk relatif sama pada peak-peak bilangan gelombang yang tidak jauh berbeda.

\section{Ucapan terima kasih}

Terima kasih kami sampaikan kepada Balai Riset dan Standardisasi Industri Padang yang telah membantu pendanaan sehingga penelitian dapat berjalan baik dan lancar. Terima kasih juga kami sampaikan kepada Yurnita yang telah membantu terlaksananya penelitian ini.

\section{Daftar pustaka}

Agustini, S., Priyanto, G., Hamzah, B., Santoso, B., Pambayun, R., 2015. Pengaruh modifikasi proses terhadap kualitas sensoris kue delapan jam. J. Din. Penelit. Ind. 26, 107-116.
Berta, S., Koapaha, T., Mandey, L., 2017. Pemanfaatan kolang-kaling buah aren dan nanas (Ananas comosus 1. merr.) dalam pembuatan sliced jam. E-Journal UNSRAT 1.

BSN, 1995. SNI 01-2802-1995 Agar-agar tepung.

Dameswari, A.H., 2017. Kombinasi teknologi kemasan dan bahan tambahan untuk mempertahankan mutu kolang-kaling. JTEP J. Keteknikan Pertan. 5, 201208.

Fitrilia, T., Nur'utami, D.A., Shapariah, R., 2019. Karakteristik fisikokimia serbuk kolang kaling (Arenga pinnata merr) berdasarkan variasi perendaman. J. Agroindustri Halal 5, 104-112.

Haris, R., Santosa, G.W., Ridlo, A., 2013. Pengaruh perendaman air kapur terhadap kadar sulfat dan kekuatan gel karaginan rumput laut Kappaphycus alvarezii. J. Mar. Res. 2, 1-10.

Hartati, I., Widiasmadi, N., Subantoro, R., Kurniasari, L., Darmanto, 2016. Penguatan usaha pengolah kolang kaling di desa ngesrepbalong kecamatan limbangan Kabupaten Kendal. Momentum 12, 1722.

Hussin, S.A.M., Sapawi, C.W.N.S.C.W., Anzian, A., Ramli, H.B., 2017. Aqueous extraction, purification and characterization of galactomannans from aren sugar palm (Arenga pinnata) fruits. Int. J. Adv. Sci. Eng. Inf. Technol. 7, 1148-1154.

Irwanto, Sahupala, A., 2015. Pemanfaatan buah aren (Arenga pinnata merr) untuk peningkatan pendapatan petani desa Hatusua. Kabupaten Seram Barat. BAKTI-UNPATTI (Journal Community Serv. 4, 7683.

Lakshmi, C., 2014. Food coloring: The natural way. Res. J. Chem. Sci. 4, 87-96.

Lempang, M., 2012. Pohon aren dan manfaat produksinya. Info Tek. EBONI 9, 37-54.

Manambangtua, A.P., Hutapea, R.T., Wungkana, J., 2018. Analisis usaha tani aren (Arenga pinnata merr), di kota Tomohon, Sulawesi Utara. J. Sos. Ekon. Pertan. 14, 85-92.

Mechlouch, R.F., Elfalleh, W., Ziadi, M., Hannachi, H., Chwikhi, M., Aoun, A. Ben, Elakesh, I., Cheour, F., 2012. Effect of different drying methods on the physico-chemical properties of Tomato variety'Rio grande'. Int. J. Food Eng. 8. https://doi.org/10.1515/1556-3758.2678

Purwati, Nugrahini, T., 2018. Pemanfaatan buah kolang kaling dari hasil perkebunan sebagai pangan fungsional. J. Abdimas Mahakam 2, 24-33.

Ratima, S., 2014. Khasiat tersembunyi kolang kaling. Url. https://tabloidsinartani.com/detail/indeks /olahan-pasar/612-khasiat-tersembunyi -kolangkaling (akses 9.19.19).

Safriani, N., Novita, M., Sulaiman, I., Ratino, W., 2014. Pengemasan manisan kolang kaling (Arenga pinnata 1.) dengan bahan kemas plastik dan botol kaca pada penyimpanan suhu ruang. J. Rona Tek. Pertan. 7, 3144.

Sarastuti, M. dan, Yuwono, S.., 2015. The effect of oven and heating time on rujak cingur instant seasoning's characteristics during storage. J. Pangan dan Agroindustri 3, 464-475. 
Sarmi, Ratnani, R.D., Hartati, I., 2016. Isolasi senyawa galaktomanan buah aren (arenga pinnata) menggunakan beberapa jenis abu. Momentum 12, $21-25$.

Simpson, B.K., 2012. Food biochemistry and food processing, Second Edi. ed. Wiley-Blackwell is an imprint of JohnWiley \& Sons, formed by the merger ofWiley's global Scientific, Technical and Medical business with Blackwell Publishing. Editorial.

Siregar, E.A., Rusmarilin, H., Limbong, L.N., 2015. Pengaruh lama blansing dan jumlah gula terhadap mutu manisan. J. Rekayasa Pangan dan Pertan. 3, 212-216.

Tarigan, J., 2012. Karakteristik edible film yang bersifat antioksidan dan antimikroba dri galaktomanan biji aren (Arenga pinnata) yang diinkorporasi dengan minyak atsiri Daun Kemangi (Ocimum basilicum). [disertasi]. sumatera utara: fakultas matematika dan ilmu pengetahuan.

Tusiyem, T., Suroso, A., Retnowaty, S.F., Wirman, S.P., 2015. Uji fisis dan ph manisan air buah kolang kaling. J. Phot. 5, 53-62.

Yenrina, R., Anggraini, T., Maulana, Z., 2017. Chemical characteristics of fruit leather mixture of kolang kaling (Arenga pinnata) and jackfruit (Artocarpus heterophyllus). Int. J. Adv. Risearch 5, 897-902. https://doi.org/10.21474/IJAR01/5602

Yuliani, N., Maulinda, N., Sutamiharja, R., 2012. Analisis proksimat dan kekuatan gel agar - agar dari rumput laut kering pada beberapa pasar tradisional. J. Siains Nat. Univ. Nusa Bangsa 2, 102-115. 